\title{
Moving Pictures and Medicine in the First Half of the 20th Century: Some Notes on International Historical Developments and the Potential of Medical Film Research
}

Christian Bonah and Anja Laukötter

Keywords: moving pictures; medicine; first half of the 20th century; medical film; international film

\section{Introduction}

Images shape our understanding of the world. Motion pictures have been essential in establishing relationships between science, medicine and society in the 20th century. As such, the production, distribution and screening of films are events in the history of medicine and health, just as much as medical films are a constitutive part of film history. Moreover, medical films are part of the wider setting of 20th-century mass education practices, be it as instructional and training films for professionals, or as health education films for the general public. In both cases they have played a crucial role in movements of public hygiene, social hygiene, and ultimately public health. Accordingly, medical films are a fascinating observatory for studying the cultural production of scientific representations of "reality," as well as the translation and integration of those representations into public perceptions of health and disease.

Christian Bonah, Institut universitaire de France \& Institut de Recherche Interdisciplinaires sur les Sciences et la Technologie (IRIST EA 3424), Faculté de Médecine, Université de Strasbourg, 4, rue Kirschleger, F-67085 Strasbourg Cedex (Christian.Bonah@medecine.u-strasbg.fr).

Anja Laukötter, Institute for the History of Medicine (Campus Mitte), Charité - Universitätsmedizin Berlin, Ziegelstrasse 5-9, D-10117 Berlin (anja.laukoetter@charite.de). 
As films gradually emerge from their marginal, complementary and illustrative historiographic location, today's historians conceive them as independent sources with their own epistemic status. They are no longer considered to be media that simply record and document, but reconstructions of the past and the present that are structured by the way in which they stage their subjects and by their figurative capacity.

Historical medical films have recently enjoyed increasing scientific and public interest. Science museums are featuring film cycles ${ }^{1}$, pharmaceutical industries are editing older medical films as marketing gifts ${ }^{2}$, and medical faculties are using historical films in teaching ${ }^{3}$ and research ${ }^{4}$. Despite their rediscovery and the public interest in them, we still lack a general overview of the films used for research, teaching and education during the first half of the 20th century. Two excellent and very recent histories of documentary film in Germany and Great Britain ${ }^{5}$ further illustrate the tendency to consider medical films as mere marginal by-products in a wider documentary sciencefilm history. Excellent works on medical films have been published recently. Nevertheless, we are still facing major deficits. The following paper is an attempt to address two desiderata. First, we very broadly outline a synthetic overview of key developments in medical film production from the inception of motion pictures in 1897 to the aftermath of World War II. Second, we will present the current state of research and sketch out some analytical propositions for the field of medical films, highlighting some of the potential of medical film research.

The designation "medical and health films" refers to a variety of motion pictures - dating back to the earliest applications of the cinematograph to medicine - that are chiefly comprised of medical or sanitary content, are centred on medical professionals or on expert advice derived from medical professionals. If certain recent American studies tend to consider "medicine's

1 See for example the programme of La cité des sciences La Villette in Paris which included film cycles like "Petite histoire de l'hygiène au cinéma 1900-1960", June 5-20, 2004, and "Y a-t-il un médecin dans la salle?", April 11-30, 2006. See http://www.cite-sciences.fr/ francais/ala_cite/cite_pra/agenda/global_fs_cinema.htm (accessed 01/06/2008) or the "Films of fact" exhibition at the Science Museum in London, May 30, 2008 to February 2009. See http:// news.bbc.co.uk/2/hi/uk_news/magazine/7423847.stm (accessed 01/06/2008).

2 See for example the collection of films edited and distributed by Eli Lilly Company. Collection "Ciné Psy".

3 See the collection of curricula and research programmes at the National Library of Medicine, History of Medicine Division, http://www.nlm.nih.gov/ hmd/collections/digital/syllabi and http://www.nlm.nih.gov/hmd/collections/ films.

4 Historia, Cine et medicina, Universitat Autonoma de Barcelona, January 22-27, 2007.

5 Boon 2008; Jung/Loiperdinger 2005; Kreimeier/Ehmann/Goergen 2005; Zimmermann/ Hoffmann 2005. 
moving pictures as a genre", defined by a "unique relationship to the medical profession and science", it might be argued that such a qualification runs counter to the usual distinction made between laboratory, documentary, newsreel, publicity and fiction films. Medical films include elements from all these genres and contribute to all of them in manifold ways.

The following historical overview is limited to institutional medical and health films in the sense that, from a production point of view, the films were conceived or produced by health professionals and distribution lay mainly outside the usual channels of commercial film distribution. This does not mean that commercial producers and film industrialists were not associated with the institutional films, rather the contrary, as the cases of Pathé, Gaumont and UFA will show below. However, the initial impulse behind these films usually came from outside purely commercial circles. In this sense, they can also be distinguished from commercially produced educational films. Nevertheless, their didactic qualities do not necessarily mean that these films were only documentaries or that they had no commercial aspects attached to them.

Our historical overview will proceed in roughly chronological order and take an international perspective. Although in strictly chronological terms the bulk of our presentation is taken up by the pre-1914 era, the interwar years and the post-1945 era, we give equal attention to the two wars themselves. The rationale behind this organisation is that we consider the World Wars to be significant and autonomous periods with respect to the history of medical and health films; they were intense moments of conceptual and technical change, and of actual film production ${ }^{7}$. Highlighting the two wars also emphasises that films have their proper chronological development. Finally, because our focus is on medical and health films, it seems inappropriate to exclusively subscribe to the periodisations of general film history, which is often divided into silent, sound or colour film eras. The article concludes in the 1950s, not least because the advent of public television brought profound transformations in the production, audience and distribution of films ${ }^{8}$.

6 Reagan/Tomes/Treichler 2007, 2.

7 Nichtenhauser 1954 adopts a similar structure for his manuscript, using subsections for different countries. The present article owes much insight to the unpublished Nichtenhauser manuscript deposited at the National Library of Medicine, Bethesda.

8 Obviously however, this does not imply that medical films stopped being produced at this time. On the contrary, it reflects the fact that subsequent developments are beyond the scope of this article. 


\title{
Medical and health films in an international historical perspective, 1895-1950
}

\author{
Medical films before World War I: from scientific recording to teaching \\ with films
}

The origins of the motion picture can be traced back to the serial instantaneous photography developed in 1878 by Eadweard Muybridge (1830-1904) ${ }^{9}$ and Etienne-Jules Marey (1830-1904) ${ }^{10}$. They used this technique to study and record phenomena inaccessible to direct vision. After the development of single-lens cameras between 1882 and 1892, motion picture projection began in 1895 when the Lumière brothers invented the "cinematograph", a film projector that could also be used as a camera. Initially, the invention took the general public by storm; but its novelty soon wore off and, for lack of variety, motion picture projection soon experienced its first crisis, barely a year after its inception ${ }^{11}$. For a time, motion pictures retreated back into the scientific world, where they were used as important research tools: in Glasgow John Macintyre produced the first film of X-ray pictures depicting reflex action in frog legs ${ }^{12}$; in Vienna Ludwig Braun filmed the exposed, pumping heart of $\operatorname{a~} \operatorname{dog}^{13}$; and in Berlin Paul Schuster captured motor dysfunctions in neurological patients on film ${ }^{14}$. Films usually ran for only a minute or two and were shown at scientific meetings beginning in 1897. If Schuster's films blazed a trail to the application of medical motion pictures in teaching, Braun's work underscored the use of film in scientific research to record, analyse and represent living phenomena. Schuster made clinical films in order to enhance his university lectures, for they freed him from the constraints imposed by the "case material" of his clinic and the pitfalls of direct observation. Didactically, films were used to demonstrate motor dysfunction and animal experiments to large student audiences. However, from the outset in 1897, advocates recognised that films could be used to reach not just researchers and students, but another audience as well: "Motion pictures could be employed in the most excellent manner, as demonstrations in popular-scientific lectures delivered to wide audiences." 15

9 Solnit 2003.

10 Dagognet 1987; Braun 1994; Lefebvre 2004b; Font-Réaulx/Lefebvre/Mannoni 2006.

11 Nichtenhauser 1954, 34.

12 See for details on John Macintyre and the history of X-rays Dommann 2003 and Hüppauf 2009, 146ff.

13 Braun 1897, 2025.

14 Kutner 1911, 249.

15 Schuster 1898, 196. 
Beginning in 1898, the French surgeon Eugène-Louis Doyen (1859-1916) applied medical cinematography to surgical techniques, using recordings to analyse his own practice, in hopes of improving and rationalising surgical methods and, at the same time, publicising and celebrating his own proficiency. His films were first presented at the 1898 meeting of the British Medical Association in Edinburgh ${ }^{16}$. Doyen sought to devise a technique for the rational utilisation of film, envisioning them being used didactically throughout the world. He travelled to Berlin to "record" Ernst von Bergmann and his films were shown throughout Europe. At the same time, copies of some of the approximately 100 films he produced were shown in public fairs as curiosities and main attractions, leading to bitter resentment on the part of the medical profession and a major legal battle over ownership rights with his film operator Parnaland ${ }^{17}$.

Between 1900 and 1914, the use of cinematography in biological and medical research experienced a period of intense and constant growth, much of it centred in Paris. In 1907, micro-cinematography expanded rapidly, largely due to improved equipment. With help from the Gaumont film company Julius Ries, Nicolas François-Franck, Fred Vlès and Louise Chevroton produced films showing biological phenomena, including the development of a fertilised egg. In 1908, Karl Reicher in Berlin applied the new dark-field microscope to micro-cinematography in order to display living bacteria ${ }^{18}$ and Jean Comandon collaborated with Victor Henri of the Physiological laboratory of the Sorbonne to investigate more specific on blood cells, leucocytes, bacteria and Brownian motion ${ }^{19}$.

In the US early clinical and instructional films were made in Boston by Walter G. Chase - who from 1905 onward produced motion pictures depicting epileptic seizures - and between 1908 and 1912 by T. H. Weisenburg, professor of Clinical Neurology at the University of Pennsylvania. Other authors of neuropsychiatry films in Europe included Emil Kraepelin in Munich, Hans Hennes in Bonn, H. Campbell Thomson in Great Britain and Paul Sainton in Paris. Motion picture presentations became increasingly common at the meetings of scientific and medical societies in the 1910s. In 1911, R. Kutner organised a large public demonstration of films for medical professionals at the "Kaiserin Friedrich Haus" (Empress Frederick House), an institution concerned with postgraduate medical training in Berlin. The conference theme,

16 Lefebvre 2004a.

17 Lefebvre 1996, 26-31.

18 Jung/Loiperdinger 2005.

19 Lefebvre 1993; O’Gomes 1994. 
"Cinematography applied to the Service of Science"20, bore witness to the professional recognition and acknowledgement that medical films had achieved. In the words of Nichtenhauser, this first decade of medical films can be described as one of "case-demonstration motion picture" 21 . Usually limited to a single subject or phenomena, teaching films were short and to the point, and could be easily absorbed and retained by spectators.

In terms of narrative modes and the audiences being addressed, one variation of medical cinematography involved the use of films in health education. These films started to be dramatised, such as an anti-alcoholism film produced in Berlin in 1911 which told the story of a drunkard's wife. In the same year, producers in Hamburg showed films on medical care, social services and first aid. Similar films were produced in France by Gérard Bourgeois and Marius O'Galop; and one of the earliest known films was Victimes de l'alcoolisme, produced by Pathé in $1902^{22}$. Beginning in 1910, a series of motion pictures were produced by Thomas Alva Edison for the "National Association for the Study and Prevention of Tuberculosis" in the United States. Edison's films show how, in the interests of public hygiene, the development of modern techniques of propaganda and mass media persuasion can be located somewhere between public education and physical coercion. Within two years, almost every aspect of public health, from toothbrushes to toilets, attracted the attention of US moviemakers. Typical early silent health movies, like Hope (1912) or The Temple of Moloch (1914), run for about 14 minutes and fit on one reel ${ }^{23}$. The films were usually melodramas and shown in regular commercial movie houses alongside other films. Hundreds of such films were produced by voluntary and governmental agencies, as well as by the commercial film industry. On the basis of current research, it appears that at this early stage the United States had already become the most active country in terms of health education film production ${ }^{24}$.

\section{Medical films in wartime, 1914-1918: from instruction to persuasion}

With the appearance of feature length films during World War One, motion pictures were used, to varying degrees, by the armed forces of the wartime powers for training, historical recording, public information and propaganda purposes. Film activities and medical films in the German army between

20 Kutner 1911, 249.

21 Nichtenhauser 1954, 118.

22 Lefebvre 1996, 104-124.

23 Pernick 1978; 1996.

24 Nichtenhauser 1954, 107. 
1914 and 1918 were naturally adapted to the needs of the war. There was no over-all programme or central agency in the German army responsible for wartime production and utilisation of medical films ${ }^{25}$. Some films were collected and possibly circulated by two institutions, the "Deutsche Hygiene Museum Dresden" (National Hygiene Museum Dresden ${ }^{26}$ and the "Bild-und Filmamt" (Photo and Film Office), in Berlin. Neuropsychiatry, prosthetics and rehabilitation ${ }^{27}$ were the most important topics dealt with in medical films, but thematic analysis of the films needs to be continued. The German War Department made no effort to develop and organise medical cinematography for its purposes.

After entering the war in 1917, it were the United States that used motion pictures in the most extensive and effective way. As a part of this effort and in a very short space of time, the Medical Department of the US Army established a production facility for medical films that, in terms of scope and complexity, was without precedence. An Army Motion Picture Section was established in August 1917 and the Committee on Public Information initiated large-scale production of films designed to be shown in theatres. By order of the Surgeon General the Art Department of the Army Medical Museum expanded and established a new section of the Museum in November 1917, the Instruction Laboratory ${ }^{28}$. From the end of 1917 to March 1919, the Instruction Laboratory produced or participated in the production of some 70 to 100 medical motion pictures. The films dealt with technical subjects, such as the preparation of blood cultures, surgical knots, emphysema, polio encephalitis, as well as with subjects used to train all Army personnel in first aid, dental hygiene, lice prevention and - most importantly - sexual hygiene. Some of these films formed the basis for the Mission Rockefeller that dispatched motorised film units throughout France at the end of World War I to extend the reach of health education ${ }^{29}$. The motorised units were discontinued in 1923 but later revived so that by 1930 ten film trucks, each carrying a lecturer and a driver projectionist, were in operation serving theatre-less rural communities of France and North Africa. Motorised film units were adopted by the Red Cross, in 1922/23, and other countries, including Poland, Czechoslovakia and South Africa. The National Hygiene Museum in Dresden ${ }^{30}$ used a "Hygiene-Wanderauto" in the interwar years,

25 Weiser 1919, 134-135, 142-149.

26 Schmidt 2002a, 31; Vogel 2003.

27 See the contribution by Philipp Osten in this volume for a detailed example.

28 Nichtenhauser 1954, 162.

29 Lefebvre 1996.

30 For the importance of this institution and their hygiene exhibitions, especially the Hygiene Exhibition in 1911, which attracted about eight million people, see Philipp Osten's article in this volume. 
equipped with an electric generator, a mobile tent and a projector in order to show films like Protection of Life and Health (Schutz für Leben und Gesundheit) in 1933 to rural populations in Eastern border territories (Ostgrenzlandfahrt) that were inaccessible by rail.

Even if films had proved valuable in wartime medical training, the Moving Picture Division and the Instruction Laboratory of the US Army were closed on March 1, 1919, and the production of new films ceased. In a first booklength treatise, entitled Medizinische Kinematographie ${ }^{31}$, Martin Weiser ${ }^{32}$ complained that medical films had not been able to keep up with developments in theatrical entertainment films. At the end of the war, the film industry began progressively investing in what the nation states had institutionalised during their mobilisation: public health initiatives disseminating information using the most up-to-date communication technology.

\section{Developments in the interwar period: between professionalisation} of production and efforts of coordination

In 1917, the "Universal Film Aktiengesellschaft" (UFA) was founded in Berlin as a common stock company with funds provided by the German government $^{33}$. (For a pre-history of the founding of the UFA see Philipp Osten's contribution in this volume.) UFA promptly set up an Educational Department (Kulturfilm-Abteilung). At the same time, the war cut off the supply of French educational films, which up to that time had enjoyed a near monopoly worldwide. The contributions of two men, Alexander von Rothe (a medical director and surgeon at a private hospital in Berlin) and Curt Thomalla (a resident physician in a neurological hospital in Breslau), energised and transformed UFA's plans for medical films. A detailed memorandum by Thomalla, drafted at the end of the war and proposing a production programme covering major aspects of medical education, was based on the assumption that "seeing" is of paramount importance in medical education and that it can in no way be replaced by the spoken or printed word, or by static illustrations. His proposals were accepted by the autumn of 1918, when UFA officially established the Medical Film Archives (MFA) and made Thomalla the archives' director ${ }^{34}$. Joined by Alexander von Rothe and

31 Weiser 1919.

32 For further information about Martin Weiser see the article by Francesco Panese in this volume.

33 Kreimeier 2005; von Keitz 2005; Mühl-Benninghaus 2004; Bock/Töteberg 1992; Kaufmann 1943.

34 Thomalla 1918, 1052. 
Nicholas Kaufmann, the MFA under Thomalla produced technical films for the medical profession and instructional films for non-technical audiences. During the three years in which technical films were produced approximately 100 pictures were released.

When in 1921 the government withdrew funds from the UFA and the company was forced to stand on its own feet, the production of technical films had to be abandoned. As a result, in the long run work on non-technical medical films became far more important. For example, health education films about syphilis were produced by UFA and the "Deutsche Gesellschaft zur Bekämpfung der Geschlechtskrankheiten" (German Society for Control of Sexually Transmitted Diseases), films about smallpox by UFA and the "Reichsausschuss für hygienische Volksaufklärung" (Committee for Popular Health Instruction), e.g. Smallpox, its Dangers and Control directed by C. Thomalla (1920) ${ }^{35}$, or by the UFA and the "Deutsches Zentralkomitee zur Bekämpfung der Tuberkulose" (German Central Committee for Tuberculosis Control) like The White Plague directed by C. Thomalla (1921) ${ }^{36}$. The most ambitious and consequential venture into lecture films - the Steinach Film, 1923 - addressed an issue that dominated the public imagination of all social classes at the time: sexual transformation and rejuvenation ${ }^{37}$. By the mid-1920s, financial strains and a lack of commercial viability make the "lecture films" impossible to continue and the leading producer of health films in Central Europe, UFA, stopped producing purely educational films because they had become unmarketable.

A renewed attempt to create a central film service covering the whole field of medicine was initiated by the Prussian Ministry of Education. It placed a number of rooms in the First Medical Department of the Charité - the teaching hospital of the Berlin medical school - at the disposal of von Rothe. In these rooms von Rothe created the "Medizinisch-Kinematographisches Universitäts-Institut", a department within the University of Berlin ${ }^{38}$.

By 1927, von Rothe's institute owned some 400 reels of $35 \mathrm{~mm}$ film-negatives. From this material the institute had produced several hundred films for distribution. The films covered most branches of medicine, especially surgery, orthopaedics, neurology, psychiatry, gynaecology and obstetrics. A smaller number of films were devoted to the fields of physiology, microbiology and to clinical subjects. After founding a distribution agency called the "Verlag wissenschaftlicher Filme" (Scientific Film Editions) in 1922, von Rothe began

35 Die Pocken. Ihre Gefahren und deren Bekämpfung (1920).

36 Die weisse Seuche (1921).

37 Herrn/Brinckmann 2005; Bonah/Zimmer 2009 (forthcoming).

38 Another contemporary German film producer was the Hamburg Institute for Tropical Diseases. It produced films on the biology of parasites. 
screening the films in various German cities in 1924, creating the "Medizinische Filmwoche" (Medical Film Week) and publishing a periodical "Programm der medizinischen Filmwoche" (Programme of the Medical Film Week) that, by 1927, had become a bi-weekly named "Medizin und Film" (Medicine and Film).

The structure of German academic medical film production was much too weak to withstand the depression of the late 1920s and von Rothe's institute was forced to liquidate its assets at the end of 1931. Recognising the importance of von Rothe's defunct institute, the Prussian Ministry of Education revived it in 1932 and transformed it into the "Deutsche Gesellschaft für wissenschaftliche Filme” (German Society for Scientific Films).

In France, during the interwar period, medical and scientific films continued to be produced, but French domination in the field of film production progressively declined. The year 1924 witnessed the end of the Scientific Service of the Pathé Company under the direction of Comandon. Léon Gaumont continued to support medical film production and experimentation. In 1925, the cardiologist R. Lutembacher, assisted by technicians from the Gaumont staff, produced cardiac research films and, at the same time, the company began producing health education films in cooperation with state commissions or voluntary associations responsible for fighting tuberculosis, venereal diseases and alcoholism ${ }^{39}$. Between 1919 and 1935 Pathé, Gaumont and Jean Benoit-Lévy's film company produced hundreds of medical films ${ }^{40}$.

On March 23, 1916, an Extra-Parliamentary Film Commission was formed by members of parliament, school officials, university teachers and film industrialists ${ }^{41}$. Its purpose was to study films for use in education and culture. In 1920, the Commission submitted a report to the Parliament that resulted in the creation of the "Musée Pédagogique de l'Etat" (State Museum for Education), an institution for the development and administration of teaching aids that established a rapidly expanding, central film service which acquired prints of teaching films and loaned them to schools throughout the country. In 1930, under the auspices of the Ministry of Education, Jean Benoit-Lévy organised the "Comité Français d'Etudes Médico-Chirurgicales par le Cinématographe" Studies by the Cinematograph), a group comprised of several prominent members of the medical faculty of the Sorbonne. A scientific film laboratory was established at the hospital of Villejuif, and in Professor Antoine Gosset's

39 Lefebvre 1996.

40 Loubatières 1932.

41 Commission on Educational and Cultural Films 1932; Vignaux 2007.

42 Vignaux 2007. 
department at the Salpêtrière hospital an operating room was adapted to accommodate cinematographic work. The teaching films made by BenoitLévy attracted great attention and praise for their technique and artistic perfection. The group remained active until the outbreak of World War II ${ }^{43}$.

A similar effort was undertaken by Jean Painlevé. As a biologist, he began using motion pictures in his research in 1928. Greatly attracted by film work, he founded the "Institut (français) de Cinématographie Scientifique" (Institute for Scientific Cinematography) in 1930. From 1937, Painlevé served as director of the film laboratory at the "Conservatoire des Arts et Métiers" (Institute for Arts and Engineering) in Paris. Painlevé's name became internationally known as a result of his scientific films on biological, mathemati$\mathrm{cal}$, astronomical, geological and other subjects ${ }^{44}$. (His work and his engagement with avant-garde and fantastic film elements combined with scientific documentation is further developed by Jakob Tanner in this volume.)

On an international level Great Britain ${ }^{45}$ seems to have been the major European country in which motion pictures were more slowly recognised as educational media. As late as in the mid-1920s, there was not a single department in the British Government responsible for the development of medical cinematography. Compared with other European countries, the production and use of health education films was significantly lower in Great Britain. The precise circumstances and reasons for the slow development in the UK remain to be investigated. Mainly thanks to the growing use of $16 \mathrm{~mm}$ film, after 1928 a moderate amount of film production began in Great Britain. Two films produced in 1927/28 attracted large medical audiences (The Cultivation of Living Tissue, R. G. Canti; Harvey's Circulation of Blood), but it was not until 1928 that P. Betton Done, director of the Kodak Medical Department in London, finally devised a plan to improve the situation. The plan consisted of collecting existing medical films from all parts of the world and encouraging the production of British medical films by providing advice and services. As a result, the Kodak Medical Film Library of London was founded in 1929 with a supply of some 60 films. Interest in medical films was sustained by the Kodak Medical Film Library, where the number of titles increased to 150 in 1934 and to around 200 by World War II. The collection was taken over by the British Medical Association after the war.

43 Thévenard/Tassel 1948; Vignaux 2007.

44 Millet 1994.

45 Boon 1999. 
From the 1930s onwards, it became increasingly clear that the production and distribution of medical motion pictures needed some form of central organisation or agency. The technical, economic, organisational and legislative problems connected with every aspect of their existence and use were too complex to be resolved by the initiatives of a multitude of uncoordinated groups. In 1933 the United Kingdom established the British Film Institute, a semi-official organisation representing the interests of the general public, the film industry and educational institutions. The formation of other national film agencies and organisations after the war led to a redefinition of the function of the British Film Institute. Similarly, in the United States efforts were made in 1934/35 to create an American Film Institute to sponsor educational films supported by the American Council on Education and the Rockefeller Foundation. However, the resistance of the entertainment film industry prevailed and state support ended once America entered the war. Many of the former film educators joined the Army, Navy or the Office of Education. In France various ministries remained largely responsible for organising the use of educational films. In Germany Hitler's assumption of power led to the creation of the "Reichsstelle für Film und Bild in Wissenschaft und Unterricht" (Imperial Agency for Film and Picture in Science and Instruction) in 1934, an agency that rationalised and centralised film production and use, especially in schools ${ }^{46}$. In 1940, the agency moved to new, larger facilities and changed its name from "Agency" to "Institute" (Reichsanstalt). Being state funded, up until 1943 the Agency was able to distribute over 45000 film projectors to schools, establish a system of local film distribution using more than 1200 district film libraries and circulate nearly 600000 prints of scientific and health films throughout the country - an achievement hitherto unparalleled in its scope and organisation.

Concerning research and teaching films in the 1930s and early 1940s, surgery films predominated in America, whereas in Germany a more proportionate distribution of motion pictures across all branches of medicine prevailed $^{47}$. In addition, the period in question witnessed marked advances of the use of motion picture as research tool in Germany and France, thanks to the development of special cinematographic equipment. At the same time, the mid-1930s witnessed a considerable development of the documentary as a film genre in the United States. Between 1938 and 1941 this led to the 
production of a series of health education films on tuberculosis prevention designed to reach ethnic minorities. Employing documentary techniques, the films were directed by Edgar Ulmer and produced by the National Tuberculosis Association.

If the 1930s can be portrayed as a period of steady, but unspectacular growth of non-theatrical medical films, the 1940s, and especially the Second World War, witnessed a steep rise in the production of war training films. These efforts soon took on gigantic proportions ${ }^{48}$. Paradoxically, the increase of medical film production during this period is inversely proportional to our knowledge about it. Aside from studies of Nazi Germany films ${ }^{49}$ and a few specific studies on individual films ${ }^{50}$, we face an imposing terra incognita. In all of the belligerent countries the necessities of war forged the motion picture into a powerful tool that was put to use in the nations' expanding war efforts. At the same time, mobilisation created coordinating structures that oriented and organised film production and distribution on national and international levels. However, the war also transformed peoples' exposure to film. Thousands of soldiers participated, in one way or another, in film production and many scientists and physicians became fascinated by this work and carried on with it after the war. Furthermore, it was a time of national cohesion when the film industry and educators joined forces, recruiting Hollywood studios for four years as production companies of the US Army. This close association can be illustrated by the 1940 Warner Brother production of Dr. Ehrlich's Magic Bullet, a major Hollywood biopic made possible by a collaboration aligning the Surgeon General Thomas Parran's anti-VD interests and Warner's opposition to Nazism ${ }^{51}$, or by Walt Disney's 1943 cartoon Defense against Invasion, which combined war propaganda with the war on bacteria. After 1945, the films produced during the war were used in research, education and training. Continuities abounded as American film productions became part of post-war reconstruction efforts and many films were translated into European languages, including the Disney productions.

Beyond film exchanges, it was UNESCO that put forth a "world plan programme of work in the mass media - films, radio and press" 52 in 1947. The plan created a commission charged with assessing immediate technical and raw material needs (film stock, cameras and projectors). The commission

48 Nichtenhauser 1954, HF 1.

49 Roth 1985; Rost 1987; Hachmeister 1992; Schmidt 2002b.

50 Lederer/Parascandola 1998.

51 Lederer/Parascandola 1998.

52 Anonymous 1947. 
also produced a survey of films and other direct services in 1947, eventually becoming the United Nations Film Board, responsible for coordinating all the film work of the UN's special agencies, especially the FAO and the WHO. World War II thus directly triggered post-war international organisation and influenced health information campaigns that were waged immediately after the war by international organisations, such as the International Tuberculosis Campaign, UNICEF and WHO. In 1951, these efforts were themselves depicted on screen in Croisade pour la santé/Health Crusade.

\section{Images, boundaries, persuasion}

As historical sources motion pictures are not new ${ }^{53}$. However, the questions that historians have posed to them have been revised considerably since the $1970 \mathrm{~s}^{54}$. Emerging from their traditionally marginal and subordinate status, they have become legitimate sources in their own right, enjoying unique epistemic status. In their encounter with film most historians have paid very little attention to medical films. Historians of medicine have not fully exploited the considerable potential that films harbour as unique historical sources and phenomena either. In this sense, medical films can still be considered historiographic orphans.

It is even more surprising that excellent recent studies in the history of documentary film in Germany $y^{55}$ and the $\mathrm{UK}^{56}$ have skirted around films on medical research, teaching and education. While they do establish some links between scientific and medical films and briefly compare them with other more standard forms of documentary film, they nevertheless continue to marginalise them. The most obvious reason for this lacuna is the fact that the professional film press does not cover medical films and, accordingly, information about them is hard to come by.

Studies like the ambitious three-volume French cultural history of the body $^{57}$, especially in its third volume on the 20th-century transformation of the gaze of the body, pay considerable attention to the visual mass culture of normal and abnormal bodies and their presentation in films. Nevertheless, they remain suspiciously silent on the inherent links between mass entertainment and factually oriented medical and health films. Similarly, recent

53 Ferro 1977; Osolin 1988.

54 Delage/Guigueo 2004.

55 Jung/Loiperdinger 2005; Kreimeier/Ehmann/Goergen 2005; Zimmermann/Hoffmann 2005.

56 Boon 2008.

57 Corbin/Courtine/Vigarello 2006. 
literature in the history of science and in film studies agrees that scientific motion pictures predate entertainment films ${ }^{58}$. On the one hand, images have received increasing attention in the historiography of science, where interest has grown in the role played by graphic devices used to register, inscribe and display bodily and other natural phenomena, thereby effectively producing their own visual "reality" 59 . Although the status of images used by scientists (be they animated or not) has become central to the concerns of historians of science ${ }^{60}$, scholars have continued to distinguish between so-called research and teaching films and other documentary or fictional productions. This distinction effectively reifies the classic and debatable division between objective scientific phenomena and subjective authorship. On the other hand, analyses that can accommodate both fact and fiction create problems of their own. One example is the recently published study "Mr. Münsterberg und Dr. Hyde" "61, which includes articles dealing with the history of both fiction and non-fiction films about human experiments from the beginning of the 20th century to the present. Films such as Dr. Mabuse, The Invisible Man or Germanin can teach us about the connections that link science and popular culture and about the relationship between films and the experimental practices of human observation. In the process however, we risk losing the distinctive characteristics of medical films.

A growing number of case studies devoted to specific subjects or individual films indicate researchers' growing interest in medical films. However, only a couple of monographs have been published ${ }^{62}$ alongside collections of essays, individual articles ${ }^{63}$ and other related publications ${ }^{64}$. In general, these studies tend to analyse individual films or events, often ignoring the wider medical film context and overlooking important distinctions between the North American and the European situations.

One of the major areas of inquiry concerns the techniques deployed in medical films to persuade their audiences. One example of this kind of work is Ramon Reichert's "Im Kino der Humanwissenschaften" 65 , a history that focuses on medical films from their beginning up to the end of the 20th century. Drawing on the work of Michel Foucault and Gilles Deleuze, Reichert reads the production and use of medical films strictly in terms of technolo-

58 Tosi 1986.

59 Cartwright 1995; Fox/Lawrence 1988; Gilman 1995.

60 Daston/Galison 2007.

$61 \mathrm{Krause} /$ Nicolas 2007.

62 Boon 1999; Riehl-Halen 1998; Köhne 2009; Lefebvre 2004a.

63 Kreimeier/Ehmann/Goergen 2005; Lefebvre 1993; Cantor 2007.

64 Hediger/Vonderau 2007; Pethes 2005; Holl 2002.

65 Reichert 2007. 
gies of power, control and normalisation. Without clearly defining which film corpus he is analysing and the criteria used for its selection, the empirical foundation of his study is built on shifting ground.

A second major area of interest in the history of medical films concerns the invention of the medical film as an historical event between 1897 and 1910. Prominent figures such as Eugène-Louis Doyen or Jean Comandon ${ }^{66}$ and their involvement in establishing medical film-making, have attracted much attention in recent works. Additionally, a strong case has been made for linking early film history to the efforts of scientists and physicians to present - and represent - the basic phenomena of life to scientific audiences and the lay public in the second half of the 19th century ${ }^{67}$.

A third topic that has attracted much attention in recently published articles and books concerns the propagandistic aims of medical films in the First and Second World Wars ${ }^{68}$. Particular interest has been paid to the National Socialist regime in Germany and the relationship between Nazi science, propagand ${ }^{69}$ and eugenics ${ }^{70}$. As important as these studies are in analysing the war and the regime itself, they need to be extended (at least to a certain extent) to include developments both before and after the war. The German "Volksbelehrungsfilme" or the English educational films ${ }^{71}$ that were produced at the very beginning of the 20th century served explicitly propagandistic purposes. As Harry E. Kleinschmidt from the American National Tuberculosis Associations remarked in 1919, health education combined with propaganda produced "mental inoculation", the avowed goal being "willcontrol [...] through education" "72. Additionally, the massive censorship practised in many countries before World War II can be understood as an indirect form of propaganda: in a Foucaultian sense it represented an attempt by the state to control the fantasies released by these films. A reconsideration of our analytical terms seems to be necessary.

A final consideration concerns the geographical settings in which medical films are analysed. In the current literature there is a tendency to read them in the context of national narratives. A recent collection of essays entitled "Medicine's Moving Pictures. Medicine, Health, and Bodies in American Film and Television" completely neglects the international and transnational

66 Lefebvre 2004a.

67 Martinet 1994; Robnik 2002; Schiller 1998.

68 Benzenhöfer/Eckart 1990; Oppelt 2002.

69 Rost 1987; Schmidt 2002b; Roth 1985; Prümm 2003; Giesen 2004.

70 Pernick 1996; Hachmeister 1992; Bonah/Lowy 2006.

71 Boon 1999.

72 Kleinschmidt 1919, 27.

73 Reagan/Tomes/Treichler 2007. 
dimensions of medical films. Although the volume contains some excellent articles, nowhere do the authors reflect on the influence of American films on Europe and vice versa, especially during the two world wars.

We can draw two conclusions from this assessment of contemporary research on the history of medical films. First, we lack a more comprehensive and systematic approach towards the study of medical films. And second, medical motion pictures are rarely treated as visual images, nor are they considered as independent objects and phenomena, mediating between different social and professional worlds. Therefore, we suggest interpreting 20th-century medical films as boundary objects - a concept introduced by Susan L. Star and James R. Griesemer some twenty years ago ${ }^{74}$. Applied to our context, we suggest considering geographic boundaries (national/international); professional boundaries; narrative boundaries (facts/fiction); and finally, boundaries of communication (information/persuasion/propaganda). We intend to argue for a better understanding of the epistemic status of medical films, recognising that they are instable and transnational objects that mediate different worlds, be they nations, professions, audiences or visual communities.

\section{National boundaries and international images}

Since the inception of medical motion pictures, producers have travelled with their cameras and films have been copied, sold and distributed around the world. These films were not only cultural productions that transported ideas and visions of health care across national boundaries, in the minds of many medical scientists and social reformers the films also facilitated international and transnational cooperation, not least because visual media functioned as a kind of universal language. In the international environment in which the film industry found itself from the outset (fluctuating between competition and cooperation) the boundaries encountered by film producers were chiefly twofold: geographic and economic. A few examples bear out this point. In 1912, the German film Zahnpflege an den Schulen was produced by the French film industrialist Pathé, but the professional expertise on which the film drew came from the German Committee for School Dental Care ${ }^{75}$. In 1928/29, the German "Reichsausschuss für Hygienische Volksbelehrung" (State Committee for Hygienic Instruction) turned to the National Motion

74 Star/Griesemer 1989.

75 Berliner Tageblatt, 24. November 1912. 
Pictures Co. in Indianapolis, hoping to swap films such as Fly Danger ${ }^{76}$ in order to reduce production costs. And early on, educators and scientists established the idea of an international institute for the exchange of medical films ${ }^{77}$ - a project that was still in place in the 1950s. After production was finished, medical films existed in multiple copies and were circulated, exchanged and exported. Walter Ruttmann's Feind im Blut (1931), advised by the "Deutsche und Schweizerische Gesellschaft zur Bekämpfung der Geschlechtskrankheiten" (German and Swiss Society for Control of Sexually Transmitted Diseases) and produced by the Swiss Präsens-Film-AG in Zurich, was shown almost simultaneously in Berlin and Paris. In so far as films succeeded in drawing on universal images, they participated in the creation of a system of visuality that transcended national borders, in which pictures were shared and propagated internationally ${ }^{78}$.

At the same time, the circulation of images defied national conventions. Films were adapted by cutting or inserting various scenes, depending on the audience being targeted. For example, two versions of the film Steinachs Forschungen were circulated, one for a scientific audience and another for popular consumption. Lazar Wechsler, director of the Swiss Präsens-FilmAG and producer of the highly successful and controversial anti-abortion film Frauennot - Frauenglück (1929), which was shot in the "UniversitätsFrauenklinik Zürich" (Gynaecological Clinic Zurich), directed by Edouard Tissé and shown in Austria, Switzerland and Germany, adapted his film for French audiences, releasing it under the title L'Appel de la vie ${ }^{79}$. In 1937/38 he attempted to reissue the film, including new footage shot in France and a new title: Le droit à la vie. Political limitations on the universalisation of film images were poignantly demonstrated by French government censors who, in denying a visa for the film's screening, thwarted the attempts to reissue the film in France in $1938^{80}$.

76 BA R86/937 Bd. 1.

77 BA R86/937 Bd. 1.

78 Thomalla 1922, 590.

79 BA, FA Berlin, Censorship Cards 27475, Sign. 893. Michael Geiges has provided us with additional information on the film direction by Emil Berna and Sergej Eisenstein. Microhistorical studies of individual film productions illustrate that films are not stable historical objects because they were often reorganised, transformed, translated and readapted to specific localities or audiences and accordingly different versions of a same film title are quite frequent. Furthermore, they were often collectively produced and directed. Studies of individual historical medical films indicate that precise information about the film production (including people involved, place of production, first release, etc.) differs to a certain extent depending on the archival sources used. Rarely developed in detail, these differences themselves are interesting observations worthwhile for further investigation in medical film studies.

80 Lefebvre 1996, 234-239. 
It was not just the films themselves that embarked on international "travel", but also the production techniques, such as slow motion, time lapses and microcinematography ${ }^{81}$. An example of this was the so-called "Rothe Apparatus". Developed by the Berlin surgeon von Rothe, the apparatus involved a camera technique for filming operations without endangering patients' lives. The apparatus was celebrated in the press and exported to international markets by the prestigious German optical firm Carl Zeiss in Jena, which could draw on a long tradition of exporting lenses and microscopes dating back to the mid-19th century ${ }^{82}$. In 1928, the introduction of the $16 \mathrm{~mm}$ Kodacolor film by Eastman Kodak led to fundamental changes in distribution: thanks to lower costs and simplified fire safety regulations, Kodacolor film was adapted quickly throughout the US and by other European countries as well ${ }^{83}$.

\section{Professions and visions}

In their conceptualisation, production and distribution medical films transgressed professional boundaries and required cooperation between medical scientists, film directors, audiences, the film industry, actors, patients, and nation states. The interests of these different actors were at times contradictory, at times complementary, such that relations amongst them fluctuated between mutual cooperation and open hostility.

As experts on health, physicians and scientists were responsible for the information content and medical advice delivered by the film. Their names and reputations validated the film's information content and, through the film's visual images, they became the physical representation of scientific proof. Physicians were named in the front credits and appeared in the films "playing" themselves. Heinrich A. Gins, for example, the director of the smallpox department at the Robert Koch Institute, appeared in Smallpox, its Dangers and Control. Throughout Germany, France and the US, medical and hygiene societies assumed the role of advisors to film producers. These voluntary associations ${ }^{84}$ were usually comprised of physicians, educators, health care officials and lay representatives ${ }^{85}$.

81 Martinet 1994.

82 Hagener 2007; Degner 1923.

83 Nichtenhauser 1954.

84 Such as the already named "German Society for Control of Sexually Transmitted Diseases",

The German Central Committee for Tuberculosis Control" and the "Organisationsamt für

Säuglings- und Kleinkinderschutz" (Office for Organisation of Baby and Infant Protection),

"Deutsche Vereinigung für Krüppelfürsorge" (German Union for the Disabled Care). 85 Thomalla 1922, 591. 
Aside from the information content itself, film directors were responsible for transforming that content into a film narrative, that is to say, into a spectacle. Directors exerted powerful influence over the films: their character, social background and artistic appreciation, their interpretation and treatment of the medical topic, as well as their cinematographic experiences and skills all found their way into the crucible of the production process. Nicholas Kaufmann and Curt Thomalla, both film directors and physicians, shaped and structured the early history of the UFA in a decisive way. Thomalla in particular envisioned health education films as reaching "into every last nook and cranny" of society and influencing the "psyche of the masses" $"$. Across professional boundaries directors like Thomalla and their films participated in utopian projects that sought to improve society and public hygiene through the popularisation of medicine and healthiness.

Other examples of productive cooperation include the US films produced by the "National Tuberculosis Association" under the auspices of its director Edgar Ulmer and the physician Harry E. Kleinschmidt. However, cooperation could also lead to conflict, as happened in the trial pitting the film director Ambroise-François Parnaland against Eugène Doyen in 1908 in a dispute over ownership rights ${ }^{87}$. If contradictory interests did not always lead to open conflict, the production history of UFA's 1923 Steinach-Film produced with the aim of popularising Eugen Steinach's theories of sexual difference - indicates that cooperation could result in a confused montage of laboratory insights and fiction sequences. In the words of the film director Curt Thomalla: "We wanted a film; he wanted a work of science. Our goal was the end-product on the screen and its public impact; he dreamed of receiving a Nobel prize" $"$.

\section{Scientific facts and entertainment}

From the very beginning, motion pictures were comprised of a tangled web of factual registration, subjective authorship and public entertainment. The works and films of Eugène-Louis Doyen are a case in point. A surgical operation filmed in 1902 and showing Doyen separating the Siamese twins Doodica and Radica, who had been member of the Barnum \& Bailey Circus, clearly demonstrates not only that documentation of reality could itself

86 Thomalla 1922, 591f.

87 Lefebvre 1996, 26-31.

88 Nichtenhauser 1954. 
be spectacular, but also that factual films dedicated to knowledge, education and the wonders of nature were caught up in a web of cultural and social determinants.

A motion picture about electrical accidents produced by Stephan Jellinek for the International Health Exposition in Dresden in 1911 is probably the first film to be made by a physician in which the subject is given a methodological and complex treatment (content outline) that requires staged action throughout the film. The film introduces a new pattern of film-making that involved cooperation between many experts: a film production company provided cinematographic advice, a plotline was drafted and the subject matter was reorganised in methodological sequence and arranged in three parts and fifteen dramatised scenes.

These films addressed the film-going public and their main intention was to inform and entertain. In attempting to translate scientifically based medical problems into pictures, they used the inherent potential of the topic at hand. Films like La famille Charbonnais ${ }^{89}$ or Le baiser qui tue by Jean Choux, which sought to prevent syphilis and tuberculosis, were in their own right melodramas that articulated the medical problem in anecdotal terms. Another example is the movie The Secret Enemy by J. K. Raymond Millet, a film designed to help prevent syphilis, but which becomes more a mixed genre film, incorporating elements of fiction and documentary ${ }^{90}$.

\section{Visual regimes and body gaze}

Health education film production was based on the idea that watching moving pictures would have a favourable effect on the behaviour of audiences. This included the idea that members of the audience would accept the healthy lifestyle which the film sought to project and integrate this salubrious behaviour into their daily lives. Visual strategies to establish expert authority and at the same time to render messages understandable used in particular microscopic and physiological pictures supplying new images of the body and its sundry parts to audiences which had never seen them before ${ }^{91}$. Thus they created a new form of visibility that had not existed for the general public. The boundaries of what could be seen publicly were not only transformed by formerly invisible bacteria or body parts, but films on sexual

89 Le baiser qui tue directed by Jean Choux, 1928, $85 \mathrm{~min}$, and La famille Charbonnais directed by Jean Brocher, 1931.

90 L'ennemi secret directed by J. K. Raymond Millet, 25 min, 1945.

91 Boon 1999; Vignaux 2007. 
education were as well transgressions of social norms of visual regimes representing erotic scenes formerly controlled and refrained from the public gaze. Sex education films in this respect were boundary objects playing on ambiguities between education and erotic entertainment, between norms and desires or in other words, between the worlds of medical prevention and sex industry. (For this ambivalence especially on sexual health education, see also the article by Jakob Tanner.)

If and how these films had an impact on public attitudes and self-perceptions is open to question, but we also have other sources that help us reconstruct and interpret the past. Medical films were the object of debate not only amongst medical scientists, but also in the wider public sphere. Thus, we can read newspaper reports as mediated forms of the audience's voice. In these reports we find detailed critiques of medical films, debates about the pros and cons of their use and intentions, as well as concise descriptions of the development of educational films. These sources indicate that health education films created a new space for the cultural production of scientific representations of "reality" and their translation and integration into public perceptions. At the same time sources and debates indicate that these films participated in redefining rules and limits of visual public decency and their enforcement through censorship and policing. Evidence that medical films "reached" their audiences comes not only from reviews and public debates about individual films. We must also recognise that the state sought to control and measure the impact of medical films. New visual regimes in medical films were accompanied by new forms of visual control. Accordingly, the first attempts to interrogate the audience date from the beginning of the 20th century. By 1919, the US Interdepartmental Social Hygiene Board was cooperating with the Psychological Laboratory of Johns Hopkins University on an investigation on the effects of the medical films used in public hygiene campaigns. The venereal disease film Fit to Win was used to research film content, the reactions it produced and the effects it had on the practical lives of the spectators. This form of experimental psychology, which presaged the strategies developed later by the advertising industry, is an informative source in terms not only of audiences' answers, but also of the questions posed by the state. Censorship was another important instrument for the control of the medical gaze. Although the form and practice of censorship differed from one nation to the next (with Russia beginning early in the 20th century, France following suit in 1916, Germany centralising its censorship in 1920, and America centralising self-censorship in 1930), state supervision of public fantasies became commonplace throughout the world. Evidence of these practices sheds light on the arguments put forward to justify not only the 
censorship of certain medical films from the outset, but also the exploitation of moving pictures in the service of state interests.

\section{Conclusion}

The present paper has presented a synthetic overview of the historical development of medical motion pictures in Europe and the United States. Its purpose was to describe the analytical directions medical film studies have taken and can take in the future. Interestingly, historical medical films not only question health, life and social sciences but attract also today's public through film cycles in museums and movie theaters. This underlines the fact that historical medical films were comprised of multiple layers of meaning and that the images in them can still speak to us.

To our mind, current research indicates that medical films need to be addressed as a coherent audiovisual corpus. Furthermore, we consider that their epistemic status as visuals needs more attention. This means precisely to investigate films as images and not as texts (referring only to the plot of a film); to consider them as objects transgressing national and visual borders, and moving between different professions and forms of narratives. If medical films created new forms of visual regimes, we have to realise, just as contemporaries in the 1920s, that intended messages were difficult to control and fantasies released by the medical films built on manifold voluntary or involuntary ambiguities. Moving pictures were and are polysemous; therefore we have suggested in this paper to reconsider the analytical framework applied to medical films. It is nevertheless clear that there are many paths of inquiry into medical films that have yet to be taken - indeed, far more than this brief essay review is capable of suggesting.

\section{Archives}

Nichtenhauser, Adolf, A History of Medical Film, unpublished manuscript, National Library of Medicine, Nichtenhauser papers, Washington DC (1954)

Records of the Bundesarchiv Berlin: BA R86/937 and the Film Archives of the Bundesarchiv Berlin: Censorship Cards 27475, Sign. 893

\section{Bibliography}

Anonymous, "UNESCO's World Plans", Documentary News Letter 6/55 (1947) 67

Benzenhöfer, Udo/Wolfgang U. Eckart (Hrsg.), Medizin im Spielfilm des Nationalsozialismus (Tecklenburg 1990) 
Bock, Hans-Michael/Michael Töteberg (Hrsg.), Das Ufa-Buch. Kunst und Krisen, Stars und Regisseure, Wirtschaft und Politik (Frankfurt a. M. 1992)

Bonah, Christian/Vincent Lowy, «La propagande sanitaire par le film documentaire en France et en Allemagne. Réflexions à partir de deux exemples du milieu des années 1930: L'œuvre Grancher et Erbkrank», in: Christian Bonah/Anne Danion-Grilliat/Josiane Olff-Nathan/ Norbert Schappacher (éds), Nazisme, science et médecine (Paris 2006) 167-192

- /Alexis Zimmer, «Le calvaire du Steinach Film〉 (1922/23). Représentations du médecin dans le film de recherche et d'enseignement médical», Sociétés \& Représentations (2009) forthcoming

Boon, Timothy, Films and the Contestation of Public Health in Interwar Britain, PhD Thesis University of London (London 1999)

- Films of Fact: a History of Science in Documentary Films and Television (London 2008)

Braun, Ludwig, «Die Anwendung des Kinematographen für das Studium und die objektive Darstellung der Herzbewegung», Wiener Medizinische Wochenschrift 47 (1897) 2025-2028

Braun, Martha, Picturing Time: the Work of Etienne-Jules Marey 1830-1904 (Chicago 1994)

Cantor, David, "Uncertain enthusiasm: the American Cancer Society, public education, and the problems of movies, 1921-1960", Bulletin of the History of Medicine 81 (2007) 39-69

Cartwright, Lisa, Screening the body. Tracing medicine visual culture (Minneapolis 1995)

Commission on Educational and Cultural Films, The Film in National Life (London 1932)

Corbin, Alain/Jean-Jacques Courtine/Georges Vigarello (éds), Histoire du corps. Tome 3: Les mutations du regard (Paris 2006)

Dagognet, François, Etienne-Jules Marey: la passion de la trace (Paris 1987)

Daston, Lorraine/Peter Galison, Objectivity (New York 2007)

Degner, Ernst, «Medizinische Kinemathographie», Deutsche Allgemeine Zeitung (11.3.1923)

Delage, Christian/Vincent Guigueo, L'historien et le film (Paris 2004)

Dommann, Monika, Durchsicht, Einsicht, Vorsicht. Eine Geschichte der Röntgenstrahlen 18961963 (Zürich 2003)

Ferro, Marc, Cinéma et histoire (Paris 1977/1993)

Font-Réaulx, Dominique/Thierry Lefebvre/Laurent Mannoni (éds), EJ Marey - Actes du Colloque du Centenaire (Paris 2006)

Fox, Daniel M./Christopher Lawrence, Photographing Medicine: images and power in Britain and America since 1840 (New York 1988)

Giesen, Rolf, Nazi Propaganda Films. A History and Filmography (McFarland 2004)

Gilman, Sander L., Health and Illness: images of difference (London 1995)

Hachmeister, Sylke, Kinopropaganda gegen Kranke. Die Instrumentalisierung des Spielfilms «Ich klage an» für das nationalsozialistische «Euthanasieprogramm» (Baden-Baden 1992)

Hagener, Malte, «Licht, Kamera, Reflektion. Das Wunder von Jena und die Industriefilmproduktion bei Carl Zeiss», in: Hediger, Vinzenz/Patrick Vonderau (Hrsg.), Filmische Mittel, industrielle Zwecke. Das Werk des Industriefilms (Berlin 2007) 282-291

Hediger, Vinzenz/Patrick Vonderau, Filmische Mittel, industrielle Zwecke. Das Werk des Industriefilms (Berlin 2007)

Herrn, Rainer/Christine N. Brinckmann, «Von Ratten und Männern: Der Steinach Film», Montage A/V, Nr. 14/2 (2005) 78-100

Holl, Ute, Kino, Trance und Kybernetik (Berlin 2002)

Hüppauf, Bernd, «Der Frosch im wissenschaftlichen Bild», in: Bernd Hüppauf/Peter Weingart (Hrsg.), Frosch und Frankenstein. Bilder als Medium der Popularisierung von Wissenschaft (Bielefeld 2009) 137-164

Jung, Uli/Martin Loiperdinger (Hrsg.), Geschichte des dokumentarischen Films in Deutschland. Band 1: Kaiserreich 1895-1918 (Ditzingen 2005)

Kaufmann, Nicholas, «Das Kulturfilmschaffen der Ufa», in: H. Traub (Hrsg.), Die Ufa. Ein Beitrag zur Entwicklungsgeschichte des deutschen Filmschaffens (Berlin 1943) 165-183

Keitz, Ursula von, «Wissen als Film. Zur Entwicklung des Lehr- und Unterrichtsfilms», in: K. Kreimeier/A. Ehmann/J. Goergen (Hrsg.), Geschichte des dokumentarischen Films in Deutschland, Band 2: Weimarer Republik 1918-1933 (Ditzingen 2005) 120-150

Kleinschmidt, Harry E., "Educational prophylaxis to venereal disease”, Social Hygiene 5 (1919) 27

Köhne, Julia B., Kriegshysteriker. Strategische Bilder und mediale Techniken militärpsychiatrischen Wissens 1914-1920 (Husum 2009) 
Krause, Marcus/Nicolas Pethes (Hrsg.), Mr. Münsterberg und Dr. Hyde. Zur Filmgeschichte des Menschenexperiments (Bielefeld 2007)

Kreimeier, Klaus, «Ein deutsches Paradigma. Die Kulturabteilung der Ufa», in: K. Kreimeier/ A. Ehmann/J. Goergen (Hrsg.), Geschichte des dokumentarischen Films in Deutschland, Band 2: Weimarer Republik 1918-1933 (Ditzingen 2005) 67-86

- IAntje Ehmann/Jeanpaul Goergen (Hrsg.), Geschichte des dokumentarischen Films in Deutschland, Band 2: Weimarer Republik 1918-1933 (Ditzingen 2005)

Kutner, R., «Die Bedeutung der Kinematographie für medizinische Forschung und Unterricht sowie für volkshygienische Belehrung», Zeitschrift für ärztliche Fortbildung 8 (1911) 249-251

Lederer, Susan/John Parascandola, "Screening syphilis: 'Dr. Ehrlich's Magic Bullet' meets the public health service", Journal of the History of Medicine 53 (1998) 345-370

Lefebvre, Thierry, «Contribution à l'histoire de la microcinématographie: de François Franck à Comandon», 1895, № 14 (1993) 35-46

- Cinéma et discours hygiéniste (1890-1930), Thèse Université Paris III (Paris 1996)

- La chair et le celluloüd. Le cinéma chirurgical du docteur Doyen (Brionne 2004a)

- (éd.), Sur les pas de Marey: science(s) et cinéma (Paris 2004b)

Loubatières, Paul-Jean Georges, Cinématographie et sciences médicales, Thèse Faculté de Médecine de Bordeaux (Bordeaux 1932)

Martinet, Alexis (éd.), Le cinéma et la science (Paris 1994)

Millet, Richard, «Jean Painlevé cinéaste», in: Alexis Martinet (éd.), Le cinéma et la science (Paris 1994) 86-94

Mühl-Benninghaus, Wolf, Vom Augusterlebnis zur UFA-Gründung: der deutsche Film im 1. Weltkrieg (Berlin 2004)

O’Gomes, Isabelle do, «L'œuvre de Jean Comandon», in: Alexis Martinet (éd.), Le cinéma et la science (Paris 1994) 78-85

Oppelt, Ulrike, Film und Propaganda im Ersten Weltkrieg. Propaganda als Medienrealität im Aktualitäten- und Dokumentarfilm (Stuttgart 2002)

Osolin, Janis, Rekonstruktion: Geschichte und Geschichten im Film (Basel 1988)

Pernick, Martin S., "Thomas Edison's tuberculosis films: mass media and health propaganda", Hasting Center Report (1978) 21-27

- The Black Stork: eugenics and the death of "defective" babies in American medicine and motion pictures since 1915 (New York 1996)

Pethes, Nicolas, "Terminal men. Biotechnological experimentation and the reshaping of 'The Human' in medical thrillers", New Literary History 36 (2005) 161-186

Prümm, Karl, «Modellierung des Unmodellierbaren. NS-Kriegspropaganda im Film und ihre Grenzen», in: Peter Zimmermann/Kai Hoffmann (Hrsg.), Triumph der Bilder (Konstanz 2003) 319-332

Reagan, Leslie J./Nancy Tomes/Paula A.Treichler, Medicine's Moving Pictures. Medicine, Health, and Bodies in American Film and Television (Rochester 2007)

Reichert, Ramón, Im Kino der Humanwissenschaften. Studien zur Medialisierung des wissenschaftlichen Wissens (Bielefeld 2007)

Riehl-Halen, Heidrun, Der deutschsprachige Tuberkulosefilm (Köln 1998)

Robnik, Drehli, «Körper-Erfahrung und Film-Phänomenologie», in: Jürgen Felix (Hrsg.), Moderne Film Theorie (Frankfurt a. M. 2002) 246-280

Rost, Karl Ludwig, Sterilisation und Euthanasie im Film des 〈Dritten Reiches $\rangle$ :nationalsozialistische Propaganda in ihrer Beziehung zu rassenhygienischen Massnahmen des NS-Staates (Husum 1987)

Roth, Karl-Heinz, «Filmpropaganda für die Vernichtung der Geisteskranken und Behinderten im 〈Dritten Reich»», in: Götz Aly et al. (Hrsg.), Reform und Gewissen. «Euthanasie» im Dienst des Fortschritts (Berlin 1985) 125-193

Schiller, Marianne, Bildkörper: Verwandlung des Menschen zwischen Medium und Medizin (Hamburg 1998)

Schmidt, Ulf, «Der Blick auf den Körper. Sozialhygienische Filme, Sexualaufklärung und Propaganda in der Weimarer Republik», in: Michael Hagener (Hrsg.), Geschlecht in Fesseln, Sexualität zwischen Aufklärung und Ausbeutung im Weimarer Kino 1918-1933 (München 2002a) 23-46 
- Medical Films, Ethics and Euthanasia in Nazi Germany: the history of medical research and teaching films of the Reich Office for Educational Films/Reich Institute for Films in Science and Education 1933-1945 (Husum 2002b)

Schuster, Paul, «Vorführung pathologischer Bewegungskomplexe mittelst des Kinematographen und Erläuterung derselben», Verhandlungen der Gesellschaft deutscher Naturforscher und Aerzte, Teil 1 (1898)

Solnit, Rebecca, River of Shadows: Eadweard Muybridge and the technological Wild West (New York 2003)

Staatliche Sammlung ärztlicher Lehrmittel, Katalog wissenschaftlicher Filme für Biologie und Medizin (Berlin 1933)

Star, Susan L./James R. Griesemer, "Institutional ecology, 'translations' and boundary objects: amateurs and professionals in Berkeley's Museum of Vertebrate Zoology, 1907-39", Social Studies of Science 19 (1989) 387-420

Thévenard, Paul/G. Tassel, Le cinéma scientifique français (Paris 1948)

Thomalla, Curt, «Ein medizinisches Filmarchiv», Berliner Klinische Wochenschrift 55 (1918) 1052

- «Hygiene und soziale Medizin im Volksbelehrungsfilm», Zeitschrift für Medizinalbeamte 35 (1922) 589-610

Tosi, Virgilio, «La science au berceau du cinéma», Cinémaction 38 (1986)

Vignaux, Valérie, Jean-Benoît Lévy ou le corps comme utopie (Paris 2007)

Vogel, Klaus (Hrsg.), Das Deutsche Hygiene-Museum Dresden, 1911-1990 (Dresden 2003)

Weiser, Martin, Medizinische Kinematographie (Dresden 1919)

Zimmer, Alexis, Der Steinach Film ou la restauration des identités sexuelles à l'épreuve de la caméra, Master Thesis Université de Strasbourg (Strasbourg 2007)

Zimmermann, Peter/Kay Hoffmann, Geschichte des dokumentarischen Films in Deutschland. Bd. 3: «Drittes Reich» 1933-1945 (Ditzingen 2005) 